\title{
U.S. Supreme Court Amicus Brief of Law Professors in Support of Petitioner, Graviss v. Department of Defense Domestic Dependent Elementary and Secondary Schools, No. 18-1061
}

Adam Steinman

University of Alabama - School of Law, asteinman@law.ua.edu

\section{Recommended Citation}

Adam Steinman, U.S. Supreme Court Amicus Brief of Law Professors in Support of Petitioner, Graviss v. Department of Defense Domestic Dependent Elementary and Secondary Schools, No. 18-1061, (2019). Available at: https://scholarship.law.ua.edu/fac_working_papers/701 
No. 18-1061

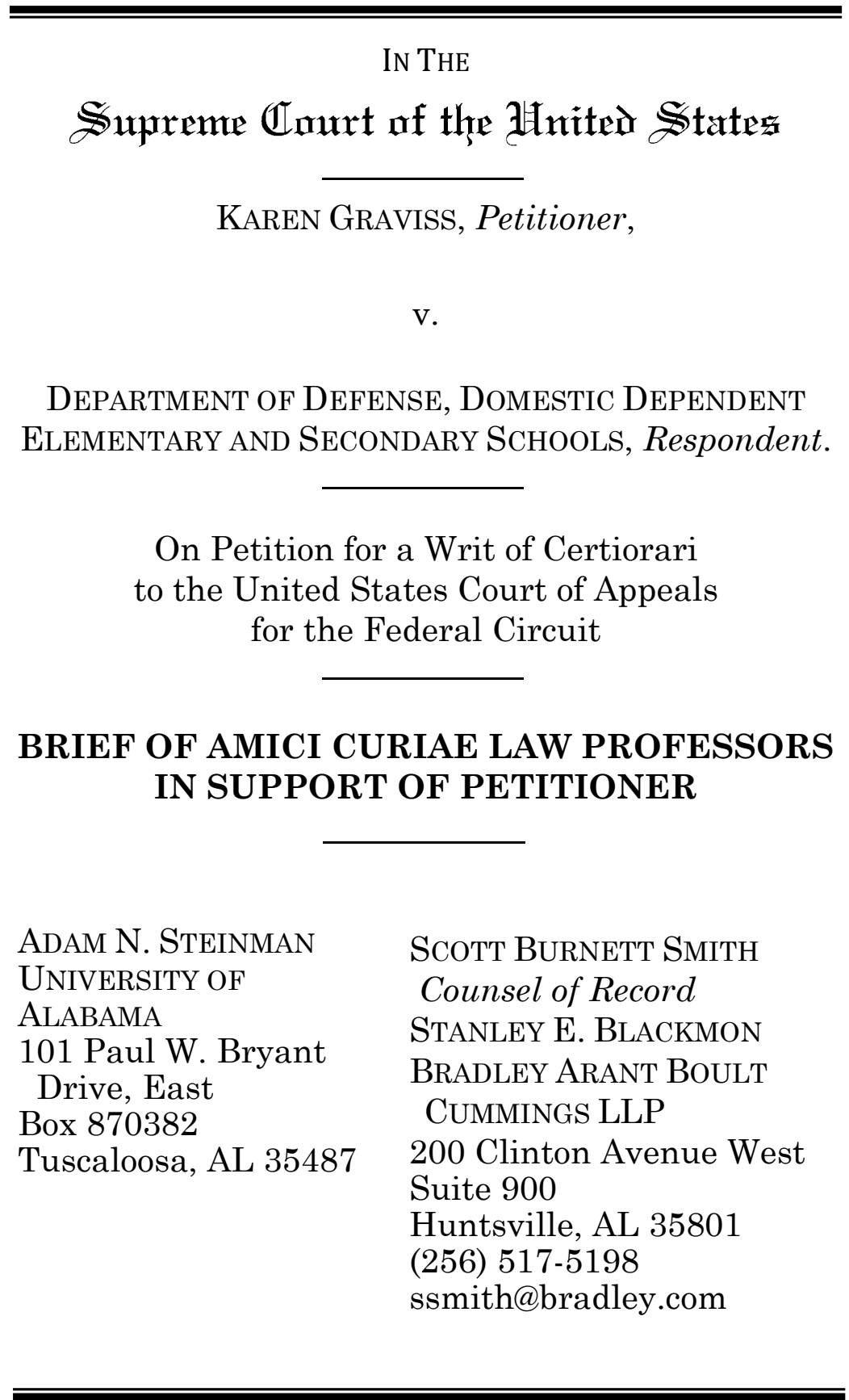




\section{TABLE OF CONTENTS}

TABLE OF AUTHORITIES ..................................... ii

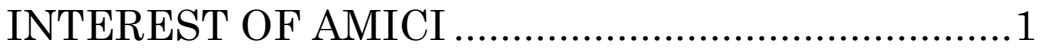

SUMMARY OF ARGUMENT ..................................

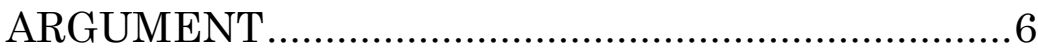

I. Treating a Requirement As Jurisdictional Has Important Practical Consequences and Should Not Be Done Lightly. .......................................... 6

II. Under this Court's Principles for Determining Which Litigation Requirements Are Jurisdictional, the Federal Circuit Must Be Reversed.

A. A Rule that Does Not Govern the Transfer of Adjudicatory Authority Between Article III Courts Is Jurisdictional Only if Congress Clearly States That It Is Jurisdictional.......................................... 11

B. Congress Has Not Clearly Stated that $\S 7703(\mathrm{~b})(1)$ 's 60 -day Deadline Is Jurisdictional.......................................... 13

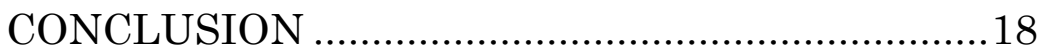

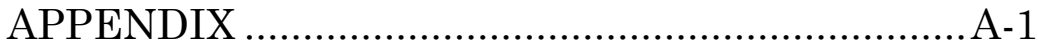


ii

TABLE OF AUTHORITIES

Page(s)

\section{Cases}

Arbaugh v. $Y \&$ H Corp., 546 U.S. 500 (2006) $1,8,10,14$

Bowles v. Russell, 551 U.S. 205 (2007) 4,11

Fed. Educ. Ass'n v. Dep't of Def., 841 F.3d 1362 (Fed. Cir. 2016) 9

Gonzalez v. Thaler, 565 U.S. 134 (2012) 11,12

Griggs v. Provident Consumer Discount Co., 459 U.S. 56 (1982) 4,11

Hamer v. Neighborhood Housing Servs. of Chi., 138 S. Ct. 13 (2017) ......................................passim

Henderson v. Shinseki, 562 U.S. 428 (2011) .passim

John R. Sand \& Gravel Co. v. United States, 552 U.S. 130 (2008) ................................. 5, 14, 15

Kontrick v. Ryan, 540 U.S. 443 (2004) passim

Nutraceutical Corp. v. Lambert,

_ S. Ct. _, 2019 WL 920828 (2019) .................... 12 
iii

Reed Elsevier, Inc. v. Muchnick, 559 U.S. 154 (2010) ............................... 1, 2, 6, 10

Sebelius v. Auburn Regional Medical Center, 568 U.S. 145 (2013) ................................. 3, 7, 8, 13

Steel Co. v. Citizens for a Better

Environment, 523 U.S. 83 (1998) .............................................. 10

Stern v. Marshall, 564 U.S. 462 (2011) .......................................... 13

United States v. Cotton,

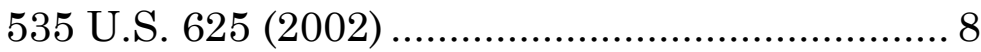

United States v. Kwai Fun Wong,

135 S. Ct. 1625 (2015) ...................................passim

\section{Statutes}

5 U.S.C. $\S$ 7703(b)(1)(A) ............................... 2, 5, 14

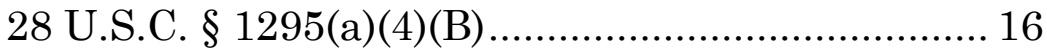

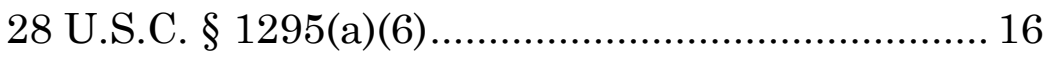

28 U.S.C. § 1295(a)(8)............................................ 16

28 U.S.C. $\S 1295(a)(9) \ldots \ldots \ldots \ldots \ldots \ldots \ldots \ldots \ldots \ldots \ldots \ldots \ldots \ldots . . . .5,15$

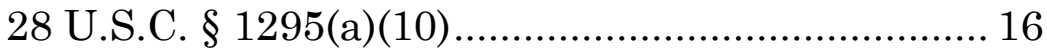

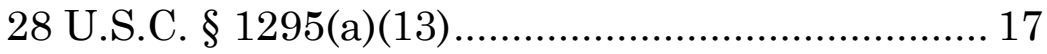


iv

28 U.S.C. $\S 2401(b)$.......................................... 14

38 U.S.C. $\S 7266($ a) ............................................ 14

\section{Other Authorities}

FED. R. CIV. P. 12(h)(3) ..................................... 7

4B C. Wright, A. Miller, \& A. Steinman, Federal Practice AND PROCEDURE

$\S 1168$ (Supp. 2018) .................................... 12 


\section{INTEREST OF AMICI 1}

Amici curiae are law professors and legal scholars from across the country with expertise in civil procedure, federal jurisdiction, and related subjects. Amici have an interest in assuring that federal courts distinguish properly between jurisdictional requirements and nonjurisdictional claim-processing rules. Amici believe that the Federal Circuit's decision below has fundamentally misapplied this Court's recent case law in this area, undermining the fairness and efficiency of the judicial system. A complete list of amici is set forth in the appendix hereto.

\section{SUMMARY OF ARGUMENT}

In recent years, this Court has frequently addressed whether to treat certain litigation requirements as jurisdictional conditions or as nonjurisdictional claim-processing rules. It has laudably strived "to bring some discipline" to the overclassification of litigation requirements as jurisdictional. Henderson v. Shinseki, 562 U.S. 428, 435 (2011). It has justifiably criticized "drive-by jurisdictional rulings," e.g., Arbaugh v. Y \& H Corp., 546 U.S. 500, 511 (2006), that have "mischaracterized claim-processing rules or elements of a cause of action as jurisdictional limitations." Reed Elsevier, Inc. $v$. Muchnick, 559 U.S. 154, 161 (2010).

${ }^{1}$ Counsel of record for all parties received notice at least ten days prior to the due date of amici's intention to file this brief. The parties have consented in writing to this filing. No counsel for a party authored this brief in whole or in part, and no person other than amici, its members, or its counsel made a monetary contribution to the preparation or submission of this brief. 
The Federal Circuit's decision below exemplifies the problem. Disregarding the letter and spirit of this Court's precedent, the Federal Circuit mistakenly treated as jurisdictional the 60-day deadline for filing a petition for review of decisions by the Merit Systems Protection Board (MSPB). See 5 U.S.C. § 7703(b)(1)(A). That Karen Graviss may have filed her petition one day beyond the 60-day window was not raised for nearly three years after her petition was filed. She and the government had litigated her due process claim on the merits in the Federal Circuit, and neither the government nor the initial panel asserted a failure to comply with the 60-day deadline. The panel ruled in Ms. Graviss's favor on the merits, and the government sought en banc rehearing in the Federal Circuitagain without asserting that the petition was timebarred. It was the en banc Federal Circuit that raised the issue for the first time, eventually concluding that the difference between 61 days and 60 days deprived it of subject-matter jurisdiction.

This result confounds this Court's recent guidance on "the 'critical difference[s]' between true jurisdictional conditions and nonjurisdictional limitations on causes of action." Reed Elsevier, 559 U.S. at 161 (brackets in original) (quoting Kontrick $v$. Ryan, 540 U.S. 443, 456 (2004)). This Court has appropriately acknowledged that deeming a requirement to be jurisdictional can thwart the fair and efficient adjudication of disputes in the federal system. And this Court has clarified that time requirements like the one at issue in this case-which does not involve "the transfer of adjudicatory authority from one Article III court to another"-can be jurisdictional only if Congress "clearly states that [it] shall count as jurisdictional." Hamer v. Neighborhood 
Housing Servs. of Chi., 138 S. Ct. 13, 20 \& n.9 (2017) (citations omitted). Because there is no such clear statement by Congress that $\S 7703(b)(1)$ 's 60-day deadline is jurisdictional, this Court should grant certiorari and reverse the Federal Circuit's decision below.

1. As this Court has recognized, giving a litigation requirement jurisdictional status has significant practical consequences. See Henderson, 562 U.S. at 434 ("This question is not merely semantic but one of considerable practical importance for judges and litigants."). It changes the "normal operation of our adversarial system," id., because a jurisdictional prerequisite must be enforced by courts on their own initiative-even if the parties have waived or forfeited any objection based on that requirement. See, e.g., Sebelius v. Auburn Regional Medical Center, 568 U.S. 145, 153 (2013) ("Objections to a tribunal's jurisdiction can be raised at any time, even by a party that once conceded the tribunal's subject-matter jurisdiction over the controversy.").

For this reason, treating a requirement as jurisdictional can severely undermine the fairness and efficiency of the judicial system. It can cause "a waste of adjudicatory resources and can disturbingly disarm litigants," id., because dismissal might be required even after the court and the parties have devoted significant resources to the litigation. See Henderson, 562 U.S. at 435 (noting that "many months of work on the part of the attorneys and the court may be wasted"). This case confirms the "drastic" consequences "that attach to the jurisdictional label." Id. Neither efficiency, fairness, nor common sense is served by blocking consideration of the merits of 
Graviss's claim because of a one-day filing delay that the government ignored during almost three years of litigation in the Federal Circuit.

2. This Court's recent decisions provide important guidance on how to distinguish jurisdictional conditions from nonjurisdictional claimprocessing rules. Crucially, it has dispensed with earlier statements indicating that "the taking of an appeal within the prescribed time is "mandatory and jurisdictional." " Bowles v. Russell, 551 U.S. 205, 209 (2007) (quoting Griggs $v$. Provident Consumer Discount Co., 459 U.S. 56, 61 (1982)). This Court has made clear that such language was "left over from days when we were 'less than meticulous' in our use of the term 'jurisdictional." Hamer, 138 S. Ct. at 21 (quoting Kontrick, 540 U.S. at 454).

In clarifying its older case law, this Court has provided a straightforward rule: if a requirement does "not involv[e] the timebound transfer of adjudicatory authority from one Article III court to another," then it must be treated as a nonjurisdictional claimprocessing rule unless Congress "clearly states" that it "shall count as jurisdictional." Id. at 20 \& n.9. Section 7703(b)(1)'s 60-day deadline does not govern the transfer of adjudicatory authority between Article III courts; it governs a direct petition to review a decision by an agency (the MSPB) in an Article III court (the U.S. Court of Appeals for the Federal Circuit). Therefore, this deadline can be treated as jurisdictional only if there is a clear statement from Congress to that effect.

Congress has made no such clear statement regarding $\S 7703(b)(1)$. Although Congress need not "incant magic words in order to speak clearly," Hamer, 
$138 \mathrm{~S}$. Ct. at 20 n.9 (citation omitted), there is no textual, contextual, or historical basis for finding a "clear indication that Congress wanted that provision to be treated as having jurisdictional attributes." Henderson, 562 U.S. at 439. The operative text contains no jurisdictional language whatsoever: "Notwithstanding any other provision of law, any petition for review shall be filed within 60 days after the Board issues notice of the final order or decision of the Board." 5 U.S.C. $§ 7703(b)(1)(A)$. The text does not refer to the authority of the court in which such a petition is filed. Nor is there a "long line of earlier cases," cf. John R. Sand \& Gravel Co. v. United States, 552 U.S. 130, 137 (2008), supporting the view that the 60-day deadline for seeking review of MSPB decisions is jurisdictional in nature.

Despite this lack of support, the Federal Circuit concluded that the 60-day deadline is jurisdictional because of 28 U.S.C. $\S 1295($ a)(9), which provides that the Federal Circuit "shall have exclusive jurisdiction ... of an appeal from a final order or final decision of the Merit Systems Protection Board, pursuant to sections 7703(b)(1) and 7703(d) of title 5." This language, however, makes no reference to the time deadline itself-it simply refers to the type of "final order or final decision" of the MSPB that the Federal Circuit may review. It is not remotely the sort of "clear indication" that is required under this Court's case law.

The lack of a clear statement by Congress means that $\S 7703(b)(1)$ 's 60 -day filing deadline cannot be treated as jurisdictional- "even when the time limit is important (most are) and even when it is framed in mandatory terms (again, most are)." United States $v$. 
Kwai Fun Wong, 135 S. Ct. 1625, 1632 (2015). A deadline does not qualify as jurisdictional where, as here, the statutory "text speaks only to a claim's timeliness" and "not to a court's power." Id. To make a time requirement jurisdictional, "Congress must do something special, beyond setting an exception-free deadline." Id. Congress has not done so here.

\section{ARGUMENT}

\section{Treating a Requirement As Jurisdictional Has Important Practical Consequences and Should Not Be Done Lightly.}

The term "jurisdiction" refers to " 'a court's adjudicatory authority." Reed Elsevier, Inc. $v$. Muchnick, 559 U.S. 154, 160 (2010) (quoting Kontrick v. Ryan, 540 U.S. 443, 455 (2004)). Properly understood, therefore, the term "applies only to "prescriptions delineating the classes of cases (subjectmatter jurisdiction) and the persons (personal jurisdiction)' implicating that authority." Id. at 160-61 (quoting Kontrick, 540 U.S. at 455)).

During the last decade or so, this Court has frequently addressed whether particular requirements, including time limits like the one at issue in this case, are jurisdictional. Henderson $v$. Shinseki, 562 U.S. 428, 434 (2011) ("In this case, as in others that have come before us in recent years, we must decide whether a procedural rule is "jurisdictional." (citing cases)); see also Hamer $v$. Neighborhood Housing Servs. of Chi., 138 S. Ct. 13 (2017) (holding that FED. R. APP. P. 4(a)(5)(C)'s limits on the extensions of time a court may grant for filing a notice of appeal are not jurisdictional); United States 
v. Kwai Fun Wong, 135 S. Ct. 1625 (2015) (holding that the time limits imposed on claims brought under the Federal Tort Claims Act are not jurisdictional); Sebelius v. Auburn Regional Medical Center, 568 U.S. 145 (2013) (holding that the statutory 180-day deadline for filing appeals to the Provider Reimbursement Review Board is not jurisdictional). This attention is well-deserved: "This question is not merely semantic but one of considerable practical importance for judges and litigants." Henderson, 562 U.S. at 434 .

Treating a particular requirement as jurisdictional is especially significant because doing so "alters the normal operation of our adversarial system." Id.

Under that system, courts are generally limited to addressing the claims and arguments advanced by the parties. ... But federal courts have an independent obligation to ensure that they do not exceed the scope of their jurisdiction, and therefore they must raise and decide jurisdictional questions that the parties either overlook or elect not to press.

Id.; see also Hamer, 138 S. Ct. at 17 ("In contrast to the ordinary operation of our adversarial system, courts are obliged to notice jurisdictional issues and raise them on their own initiative."); FED. R. CIV. P. 12(h)(3) ("If the court determines at any time that it lacks subject-matter jurisdiction, the court must dismiss the action."). When a defect is jurisdictional, it is "not subject to waiver or forfeiture and may be raised at any time in the court of first instance and on direct appeal." Hamer, 138 S. Ct. at 17 (footnote omitted); see 
also Sebelius, 568 U.S. at 153 ("Objections to a tribunal's jurisdiction can be raised at any time, even by a party that once conceded the tribunal's subjectmatter jurisdiction over the controversy."); Arbaugh v. $Y \& H$ Corp., 546 U.S. 500, 514 (2006) (“"'S]ubjectmatter jurisdiction, because it involves a court's power to hear a case, can never be forfeited or waived." " ((quoting United States v. Cotton, 535 U.S. 625, 630 (2002)).

This feature, which prohibits the forfeiture or waiver of jurisdictional requirements, can adversely affect the fairness and efficiency of the judicial system. Because a lack of subject-matter jurisdiction can be raised at any time, dismissal might be required even after the court and the parties have committed considerable time and expense to the litigation. See Henderson, 562 U.S. at 435 (noting that "many months of work on the part of the attorneys and the court may be wasted"). Such dismissals can cause "a waste of adjudicatory resources and can disturbingly disarm litigants." Sebelius, 568 U.S. at 153. A party might even wait until it loses on the merits and then opportunistically seek dismissal based on a lack of jurisdiction. See, e.g., Arbaugh, 546 U.S. at 508 (noting that the defendant lost a $\$ 40,000$ verdict and "[t]wo weeks later, . . . filed a motion under Federal Rule 12(h)(3) to dismiss [the] complaint for lack of subjectmatter jurisdiction"); Henderson, 562 U.S. at 434-35 ("[A] party, after losing at trial, may move to dismiss the case because the trial court lacked subject-matter jurisdiction.").

This particular case exemplifies the unfairness and inefficiency that results when a requirement like $\S 7703(\mathrm{~b})(1)$ 's 60 -day deadline is deemed 
jurisdictional. Although the Federal Circuit eventually found that Graviss had filed her petition for review one day late, the government had never objected to her petition on timeliness grounds. See Pet. App. 3a. Rather, Graviss and the government litigated the merits of her due process argument, and a Federal Circuit panel ruled in Graviss's favor on the merits. See Fed. Educ. Ass'n v. Dep't of Def., 841 F.3d 1362, 1362-63 (Fed. Cir. 2016). The government sought en banc rehearing from the Federal Circuit, again failing to assert that Graviss's petition for review was untimely. Nearly three years after Graviss filed her initial petition for review-and 16 months after the Federal Circuit panel found that her due process rights had been violated - the en banc Federal Circuit asked for briefing on whether her petition had met the 60-day deadline. See Pet. App. 3a. As of the date of this amici curiae brief, it has been almost 47 months since the arbitrator ruled against Graviss and 28 months since the Federal Circuit reversed the arbitrator's decision on the merits. See Fed. Educ. Ass'n, 841 F.3d at 1362. Neither efficiency, fairness, nor common sense is served by blocking consideration of the merits of Graviss's claims based on a one-day delay in filing that the government ignored during almost three years of litigation in the Federal Circuit. ${ }^{2}$

Recognizing that "the consequences that attach to the jurisdictional label may be so drastic," this Court has "tried in recent cases to bring some discipline to

2 Graviss argued at her first opportunity that the Government had forfeited its time-bar defense by failing to assert it at any point during the Federal Circuit litigation. See Pet. for Cert. 9. 
the use of this term." Henderson, 562 U.S. at 435. It has revisited earlier decisions that had "mischaracterized claim-processing rules or elements of a cause of action as jurisdictional limitations," Reed Elsevier, 559 U.S. at 161, calling them "drive-by jurisdictional rulings." E.g., Arbaugh, 546 U.S. at 511 ("We have described such unrefined dispositions as 'drive-by jurisdictional rulings' that should be accorded 'no precedential effect' on the question whether the federal court had authority to adjudicate the claim in suit." (quoting Steel Co. v. Citizens for a Better Environment, 523 U.S. 83, 91 (1998)); see also $i d$. at 510 ("This Court, no less than other courts, has sometimes been profligate in its use of the term.”).

Accordingly, this Court's recent decisions have been especially cognizant of "the 'critical difference[s]' between true jurisdictional conditions and nonjurisdictional limitations on causes of action." Reed Elsevier, 559 U.S. at 161 (brackets in original) (quoting Kontrick, 540 U.S. at 456). As the next Part shows, the broader principles this Court has developed confirm that the Federal Circuit was wrong to treat $\S 7703(\mathrm{~b})(1)$ 's 60 -day deadline as jurisdictional.

\section{Under this Court's Principles for Determining Which Litigation Requirements Are Jurisdictional, the Federal Circuit Must Be Reversed.}

This Court's recent decisions have provided important clarification on which litigation requirements must be treated as jurisdictional. Among other things, this Court has drawn a distinction between statutory deadlines "governing the transfer of adjudicatory authority from one Article III court to another," and other kinds of requirements. 
Hamer, 138 S. Ct. at 20. For requirements that do not govern the transfer of adjudicatory authority between Article III courts-like $\S 7703(b)(1)$ 's 60-day deadline for seeking Federal Circuit review of MSPB decisions-a clear statement rule applies: the requirement is not jurisdictional unless Congress "clearly states that [it] shall count as jurisdictional." " Hamer, 138 S. Ct. at 20 \& n.9 (quoting Gonzalez v. Thaler, 565 U.S. 134, 141 (2012)). This rule compels reversal of the Federal Circuit in this case.

A. A Rule that Does Not Govern the Transfer of Adjudicatory Authority Between Article III Courts Is Jurisdictional Only if Congress Clearly States That It Is Jurisdictional.

Although earlier decisions of this Court had stated that "the taking of an appeal within the prescribed time is "mandatory and jurisdictional," Bowles v. Russell, 551 U.S. 205, 209 (2007) (quoting Griggs v. Provident Consumer Discount Co., 459 U.S. 56, 61 (1982)), this Court has since clarified that this notion does not apply to the kind of deadline at issue in this case. In last Term's Hamer decision, this Court explained that this "formulation" from Bowles and earlier decisions-that appeal deadlines were "mandatory and jurisdictional"-was "a characterization left over from days when we were 'less than meticulous' in our use of the term 'jurisdictional.'" Hamer, 138 S. Ct. at 21 (quoting Kontrick, 540 U.S. at 454); see also id. (noting that several Courts of Appeals had "tripped over" this 
statement and incorrectly treated time limitations as jurisdictional) ${ }^{3}$

To address this Court's prior lack of "meticulous[ness]," Hamer drew an important distinction between (a) "a time prescription governing the transfer of adjudicatory authority from one Article III court to another," and (b) "cases not involving the timebound transfer of adjudicatory authority from one Article III court to another." Hamer, 138 S. Ct. at 20 \& n.9. Time-specifications of the second kind are nonjurisdictional claim-processing rules unless " the Legislature clearly states that a threshold limitation on a statute's scope shall count as jurisdictional.' "Id. at $20 \&$ n.9 (quoting Gonzalez, 565 U.S. at 141). ${ }^{4}$

3 This Court unanimously reemphasized this point just a few weeks ago:

To be sure, this Court has previously suggested that time limits for taking an appeal are "mandatory and jurisdictional." As our more recent precedents have made clear, however, this Court once used that phrase in a "less than meticulous" manner. Those earlier statements did not necessarily signify that the rules at issue were formally "jurisdictional" as we use that term today.

Nutraceutical Corp. v. Lambert, _ S. Ct. _ 2019 WL 920828, at *3 n.3 (2019) (citations omitted).

4 Even for time restrictions that do involve transfer of adjudicatory authority from one Article III court to another, time-restrictions imposed by federal rules rather than by Congress will not qualify as jurisdictional. See Nutraceutical, S. Ct. — 2019 WL 920828, at *3; Hamer, 138 S. Ct. at 21; 4B C. Wright, A. Miller, \& A. Steinman, Federal Practice AND PROCEDURE $§ 1168$ (Supp. 2018), at 34 ("In 2017, the Supreme Court emphasized once again the distinction between statutory and rule-based time limitations." (citing Hamer)). 
Section 7703(b)(1)'s 60-day deadline does not "involv[e] the timebound transfer of adjudicatory authority from one Article III court to another." Hamer, 138 S. Ct. at 20 n.9. It governs a direct petition to review a decision by an agency (the MSPB) in an Article III court (the U.S. Court of Appeals for the Federal Circuit). Accordingly, it can be treated as jurisdictional only if there is a clear statement from Congress to that effect. For the reasons set forth in the next Section, Congress has made no such clear statement.

\section{B. Congress Has Not Clearly Stated that $\S 7703(b)(1)$ 's 60-day Deadline Is Jurisdictional.}

As described above, this Court's recent case law provides that $\S 7703(\mathrm{~b})(1)$ 's 60 -day deadline can be treated as jurisdictional only if Congress has "clearly state[d]" that it "shall count as jurisdictional." Hamer, 138 S. Ct. at 20 n.9 (citation omitted); see also Stern v. Marshall, 564 U.S. 462, 479-80 (2011) ("Because 'branding a rule as going to a court's subject-matter jurisdiction alters the normal operation of our adversarial system,' we are not inclined to interpret statutes as creating a jurisdictional bar when they are not framed as such." (quoting Henderson, 562 U.S. at 434)). This Court has indicated that Congress need not "incant magic words in order to speak clearly," and that courts may consider "context, including this Court's interpretations of similar provisions in many years past, as probative of Congress' intent." Hamer, 138 S. Ct. at 20 n.9 (quoting Sebelius, 568 U.S. at 15354). There must be, however, a "clear indication that Congress wanted that provision to be treated as having jurisdictional attributes." Henderson, 562 U.S. 
at 439; see also United States v. Kwai Fun Wong, 135 S. Ct. 1625, 1632 (2015) ("[T]raditional tools of statutory construction must plainly show that Congress imbued a procedural bar with jurisdictional consequences." (emphasis added)).

There is no clear indication that Congress wanted $\S 7703(\mathrm{~b})(1)$ 's 60-day deadline to be treated as jurisdictional. The relevant text has no jurisdictional language whatsoever: "Notwithstanding any other provision of law, any petition for review shall be filed within 60 days after the Board issues notice of the final order or decision of the Board." 5 U.S.C. $\S 7703(\mathrm{~b})(1)(\mathrm{A}) .5$ There is no "long line of earlier cases" supporting the view that the deadline is jurisdictional in nature, cf. John R. Sand \& Gravel Co. v. United

5 This Court's case law makes clear that the word "shall" does not make a time requirement jurisdictional. See Kwai Fun Wong, 135 S. Ct. at 1632 ("The language is mandatory-'shall' be barred-but ... that is true of most such statutes, and we have consistently found it of no consequence."); Henderson, 562 U.S. at 438 (treating as non-jurisdictional a requirement that "'a person adversely affected by [a] decision shall file a notice of appeal... within 120 days" (emphasis added) (quoting 38 U.S.C. § 7266(a)); see also Arbaugh, 546 U.S. at 510 (2006) (“[I]n recent decisions, we have clarified that time prescriptions, however emphatic, are not properly typed jurisdictional." (citations omitted)). In Kwai Fun Wong, this Court addressed an especially "emphatic" statute, which provided that "[a] tort claim against the United States shall be forever barred unless it is presented [within the designated time]." 135 S. Ct. at 1632 (emphasis added) (quoting 28 U.S.C. § 2401(b)). Yet it concluded that the deadline was not jurisdictional: "[T] he language might be viewed as emphatic - 'forever' barred-but (again) we have often held that not to matter. What matters instead is that $\S 2401$ (b) does not speak in jurisdictional terms or refer in any way to the jurisdiction of the district courts." Id. at 1632-33 (citations omitted). 
States, 552 U.S. 130, 137 (2008), much less a "definitive" decision by this Court. Kwai Fun Wong, 135 S. Ct. at 1635-36 (noting that this Court's holding in John R. Sand "came down to two words: stare decisis" because that time bar "had been the subject of "a definitive earlier interpretation" " (quoting John R. Sand, 552 U.S. at 138)).

Lacking anything resembling a clear textual, contextual, or historical indicator that $\S 7703(b)(1)$ 's 60-day deadline is jurisdictional, the Federal Circuit embraced an odd interpretive theory. It reasoned that Congress made the 60-day deadline jurisdictional through the provision in 28 U.S.C. $\S 1295$ (a)(9) that the Federal Circuit "shall have exclusive jurisdiction ... of an appeal from a final order or final decision of the Merit Systems Protection Board, pursuant to sections 7703(b)(1) and 7703(d) of title 5." See Pet. App. 7a (discussing 28 U.S.C. § 1295(a)(9)). This reference, however, does not constitute the sort of "clear indication" that Congress intended the 60-day deadline to be jurisdictional. Rather, this language in $\S 1295$ (a) refers to the type of order that falls within the exclusive jurisdiction of the Federal Circuit. See Pet. App. 19a (Plager, J., dissenting) ("What is clear is that the purpose of $\S 1295$ (a) is to state which cases come to the Federal Circuit, not when they may come.").

It would be quite an interpretive leap to read $\S 1295(\mathrm{a})(9)$ as incorporating, as jurisdictional requirements, every procedural element that is referred to in those particular sections of Title 5 of the U.S. Code. See Pet. App. 40a (Wallach, J., dissenting from denial of the petition for rehearing en banc, joined by Newman \& O'Malley, JJ.) (noting that "[t]he 
sixty-day deadline is mentioned in one sentence of the two cross-referenced provisions, i.e., § 7703(b)(1) and $\S 7703(\mathrm{~d})$, with the cross-referenced provisions containing two subsections each and a total of fourteen sentences."); see also id., Pet. App. 39a ("The legislative history of $\S 1295$ confirms that the purpose of this statute is to identify which cases, by subject matter, are within our jurisdiction, rather than which timely-brought cases are within our jurisdiction." (emphasis in original)).

If taken to its logical extent, the Federal Circuit's reasoning would mean that a slew of other requirements-beyond those relating to MSPB decisions-would also be swept into the "jurisdictional" category. Section 1295(a), after all, refers to numerous sections of the U.S. Code in listing the types of orders that may be appealed to the Federal Circuit. ${ }^{6}$ Such cross-references are too thin a basis for

6 See, e.g., 28 U.S.C. $§ 1295(\mathrm{a})(4)(\mathrm{B})$ (giving the Federal Circuit exclusive jurisdiction over "an appeal from a decision of ... the Under Secretary of Commerce for Intellectual Property and Director of the United States Patent and Trademark Office or the Trademark Trial and Appeal Board with respect to applications for registration of marks and other proceedings as provided in section 21 of the Trademark Act of 1946 [15 U.S.C. $\S 1071]$ "); 28 U.S.C. $§ 1295(\mathrm{a})(6)$ (giving the Federal Circuit exclusive jurisdiction "to review the final determinations of the United States International Trade Commission relating to unfair practices in import trade, made under section 337 of the Tariff Act of 1930 [19 U.S.C. § 1337]"); 28 U.S.C. § 1295(a)(8) (giving the Federal Circuit exclusive jurisdiction over "an appeal under section 71 of the Plant Variety Protection Act [7 U.S.C. § 2461]"); 28 U.S.C. § 1295(a)(10) (giving the Federal Circuit exclusive jurisdiction over "an appeal from a final decision of an agency board of contract appeals pursuant to section 7107(a)(1) of title 
inferring a "clear purpose" by Congress to make every requirement imposed by those sections jurisdictional.

At the end of the day, there is no reason to treat $\S 7703(b)(1)$ 's 60-day filing deadline any differently from the myriad of deadlines that this Court has "[t]ime and again ... described ... as 'quintessential claim-processing rules,' which 'seek to promote the orderly progress of litigation,' but do not deprive a court of authority to hear a case." Kwai Fun Wong, 135 S. Ct. at 1632 (quoting Henderson, 562 U.S. at 435). This logic holds "even when the time limit is important (most are) and even when it is framed in mandatory terms (again, most are)." Id. Where, as here, the statutory "text speaks only to a claim's timeliness" and "not to a court's power," id., it does not qualify as jurisdictional. To make a time requirement like this one jurisdictional, "Congress must do something special, beyond setting an exception-free deadline." Id.

Accordingly, the Federal Circuit's conclusion that $\S 7703(\mathrm{~b})(1)$ 's 60-day deadline is jurisdictional cannot stand. This Court should grant certiorari to correct that mistake and "to bring some discipline" to the distinction between jurisdictional bars and nonjurisdictional claim-processing rules. Henderson, 562 U.S. at 435.

41”); 28 U.S.C. $§ 1295(a)(13)$ (giving the Federal Circuit exclusive jurisdiction over "an appeal under section 506(c) of the Natural Gas Policy Act of 1978 [15 U.S.C. § 3416]”). 
18

\section{CONCLUSION}

For the foregoing reasons, the petition for a writ of certiorari should be granted.

Respectfully submitted,

ADAM N. STEINMAN

UNIVERSITY OF

ALABAMA

101 Paul W. Bryant

Drive, East

Box 870382

Tuscaloosa, AL 35487

SCOTT BURNETT SMITH

Counsel of Record

STANLEY E. BLACKMON

BRADLEY ARANT BOULT

CUMMINGS LLP

200 Clinton Avenue West

Suite 900

Huntsville, AL 35801

(256) 517-5198

ssmith@bradley.com

Counsel for Amici Curiae

March 14, 2019 
A-1

APPENDIX

List of Amici Curiae Law Professors

(Institutional affiliation listed for identification

purposes only)

Stephen B. Burbank

David Berger Professor for the Administration

of Justice

University of Pennsylvania Law School

Erwin Chemerinsky

Dean \& Jesse H. Choper Distinguished Professor

of Law

University of California, Berkeley

School of Law

Kevin M. Clermont

Ziff Professor of Law

Cornell Law School

Brooke D. Coleman

Associate Dean of Research \& Faculty Development

$\&$ Professor of Law

Seattle University School of Law

Heather Elliott

Alumni, Class of '36 Professor of Law

Hugh F. Culverhouse Jr. School of Law

University of Alabama

Helen Hershkoff

Herbert M. and Svetlana Wachtell Professor of

Constitutional Law and Civil Liberties

New York University School of Law 
Philip A. Pucillo

Professor of Law in Residence

Michigan State University College of Law

Alexander A. Reinert

Professor of Law \& Director, Center for Rights

and Justice

Benjamin N. Cardozo School of Law

Doug Rendleman

Huntley Professor

Washington and Lee Law School

Caprice Roberts

Visiting Professor of Law

University of Florida Fredic G. Levin College of Law

Suzanna Sherry

Herman O. Loewenstein Professor of Law

Vanderbilt University Law School

Adam N. Steinman

University Research Professor of Law

Hugh F. Culverhouse Jr. School of Law

University of Alabama

Alan M. Trammell

Assistant Professor of Law

University of Arkansas (Fayetteville) School of Law

Howard M. Wasserman

Professor of Law

FIU College of Law 